\title{
Selfie Narratives Made by Young People
}

\author{
Isis Graziele da Silva ${ }^{1}$ \\ Daniel Kupermann ${ }^{1}$
}

\begin{abstract}
This study aimed to investigate the phenomenon of selfies on social networks, identifying the meanings produced by young people about their selfies and seeking to expand the understanding about this type of photography. Structured interviews were conducted with 15 college students between 18 and 28 years old that were analyzed through "applied psychoanalysis". The participants chose personal selfies and justified their publication on social networks. The interviews pointed to multiple meanings interacting with each other. Five narrative categories were created to reflect on the elements that appeared privileged in the interviewees' speech. The results showed aspects little or not discussed in the literature on the subject, revealing the plurality of meanings that exist in selfies. Thus, this study broadens the interpretation about the use that young people make of social networks and contributes with new insights to the work on this theme in contemporary clinical practice.
\end{abstract}

Keywords: photography, social networks, self concept, young adults

\section{Narrativas de Selfies Feitas por Jovens}

\begin{abstract}
Resumo: Este estudo teve por objetivo investigar o fenômeno das selfies nas redes sociais, identificando os sentidos produzidos por jovens sobre suas selfies e buscando ampliar a compreensão sobre essa modalidade de fotografia. Foram realizadas entrevistas estruturadas com 15 universitários de 18 a 28 anos que foram analisadas através da "psicanálise aplicada". Os participantes escolheram selfies pessoais e justificaram sua publicação em redes sociais. As entrevistas apontaram múltiplos sentidos interagindo entre si. Foram criadas cinco categorias de narrativa para refletir sobre os elementos que apareceram privilegiadamente na fala dos entrevistados. Os resultados demonstraram aspectos pouco ou nada discutidos na literatura sobre o tema, revelando a pluralidade de sentidos que há nas selfies. Com isso, este estudo amplia a interpretação sobre o uso que os jovens fazem das redes sociais e contribui com novos olhares para o trabalho sobre essa temática na clínica contemporânea.
\end{abstract}

Palavras-chave: fotografia, redes sociais, autoconceito, jovens

\section{Narrativas de Selfies Hechas por Jóvenes}

Resumen: Este estudio investigó los selfies en las redes sociales, identificando los sentidos que producen los jóvenes sobre sus selfies y buscando ampliar la comprensión de este tipo de fotografía. Se realizaron entrevistas estructuradas con quince estudiantes universitarios de 18 a 28 años, que se analizaron a través del "psicoanálisis aplicado". Los participantes eligieron selfies personales y justificaron su publicación en las redes sociales. Las entrevistas señalaron múltiples significados que interactúan entre sí, y se crearon cinco categorías de narrativa para reflexionar sobre los elementos que parecían privilegiados en el discurso de los entrevistados. Los resultados mostraron aspectos poco o nada discutidos en la literatura sobre este tema, revelando la pluralidad de significados que existen en los selfies. Con esto, este estudio amplía la interpretación sobre el uso que los jóvenes hacen de las redes sociales y contribuye con nuevas perspectivas para el trabajo con este tema en la clínica contemporánea.

Palabras clave: fotografía, redes sociales, autoimagen, jovenes

${ }^{1}$ Universidade de São Paulo, São Paulo-SP, Brazil

Article derived from the first author's master's thesis under the supervision of the second author, defended in 2019 at the Postgraduate Program in Clinical Psychology at Universidade de São Paulo. The study received financial support from CAPES (1722020).

Correspondence address: Daniel Kupermann. Universidade de São Paulo. Instituto de Psicologia. Av. Professor Mello de Morais, 1721, Butantã, São Paulo-SP, Brazil. CEP 05.508-030. E-mail: danielkupermann@gmail.com
In times of selfies, we are led to reflect if the record of our experiences has become more important than the experiences themselves, because certain records do not even seem to have existed as experiences. The observation of the recent valorization of self-image and the daily sharing of images of experiences on the Internet brought to our research the hypothesis that we are in a time in which, if we don't take a picture of some experience and share it with others, we feel that we have not actually experienced it. 
This raises questions: what are the subjective effects of these elements for the individual who has themselves or their experiences photographed? What is at stake when we tell our story through the specular record of our experiences? What do the young people who use this instrument so much intend to say? And yet, according to Almeida and Severiano (2017), that point to the importance of working with images in contemporary Psychology research: why the selfie has become a global phenomenon that tends to be irresistible?

Grigoletto and Wanderley (2016) suggest that today it is impossible to think the register of the self away from the virtual, because there are numerous tools that propose to virtualize lives, which points us to "other ways of materialization of subjectivity, which no longer occur only by writing, but also, by the body materialized in the image" (p. 66). In this direction, Sibilia (2016) emphasizes today smartphones give vent to the demands and ambitions that articulate contemporary subjectivities and their specific type of sociability. She states that

Technologies are invented to perform functions that society in some way requests and for which it lacks the appropriate tools. ... technological devices are the result of certain historical changes. Once created and adopted by the population, however, they end up reinforcing these transformations (Sibilia, 2016, p. 25).

One of these historical changes was that we went from the disciplinary society, in which few public men were regarded as celebrities, to another kind of social organization, in which all personalities are called upon to show themselves. So from "intro-directed personalities", analogical, we have moved to "alter-directed personalities", digital, and, as we often hear, narcissistic.

It is necessary to remember that Freud takes his conception of narcissism from the Greek myth, which has as its nodal point the relationship between Narcissus and his own image. Besides the fact that narcissism has a clinical and theoretical actuality, "no post-Freudian psychoanalysis seems to be able to do without this concept" (Estevão, 2016, p. 128). It would not be possible to extend here a trace of the construction of the Freudian concept of narcissism (primary and secondary), but it is necessary to make notes on what has been called "narcissistic postmodern man" in order to think about narcissism in its relationship with the phenomenon of selfies. For this, it is necessary to understand that the narcissism that the literature on contemporaneity deals with is not the same as that of the Freudian discourse.

According to Birman (2016), the narcissism alluded to today refers to negative narcissism, as formulated by Green (1988) in the reading of borderline states. That is, the economy of narcissism has shifted from positive to negative narcissism, a "new modality of narcissism that is currently registered in the clinical field, in the borderline states, and that is also inscribed in the social space as a privileged form of subjectivities to describe the subject in postmodernity." (Birman, 2016, p. 38).
For Green (1988), defense mechanisms such as repression, foreclosure, denial, and denial act as what he formalized as the "work of the negative". Starting from Freud, Green (1988) expanded the relations between life drive and attachment and between death drive and disconnection. The idea of disinvestment of the investment itself is one of Green's theoretical contributions, according to which the objectifying and dis-objectifying functions oscillate from one pole to another until the point of disinvestment of the ego itself is reached, configuring what he calls negative narcissism. Being related to the death drive, the only objective of negative narcissism is to reach a state in which there is no pulse excitation.

This means that the subject of the literature that discusses postmodernism - which is treated as marked by narcissism - demands the care and the look of the other about himself, demands to be narcissistically invested. For this reason, Birman (2016) points out that it is not by chance that there is such an occurrence of depression in contemporaneity, proving the loss of the power of self of the subject that has been narcissistically emptied. The contemporary subject could be considered narcissistic to the extent that he or she strives to attract the other. This points to the fact that the commonly given idea (that the subject is a narcissist because he/she thinks only of him/herself) is based on a conceptual confusion.

Freud (2010/1914) demonstrates that the goal and satisfaction in an object choice reside in being loved. Thinking about the experience of being loved and helplessness, Z. Rocha (1999) states that, helplessness reveals itself as a structuring experience of subjectivity and the human condition, and therefore, should not be considered a fatality, but a challenge for the subject.

Freudian Hilflosigkeit primarily refers to the state of the newborn, who is unable to help himself with his own resources and needs a caregiver. But besides the biological factor being at the origin of the first dangerous situations, it "creates the need to be loved, which will never abandon the human being" (Freud, 2014/1926, p. 179). In this way, the original situation of helplessness is archetypal, a model of various other situations of helplessness with which the subject is confronted in the course of existence (Z. Rocha, 1999), and it is in this sense that it met with the elements of this research. Beyond biological dependence, the helpless find themselves at the mercy of the desire of others - which is what has been discussed so much about the contemporary subject.

It is also important to emphasize what the psychoanalyst Tania Rivera presents in the project "Narcissus 21" conducted by Razé and Sibilia (2015): narcissism should be thought of as the encounter of the subject with his image, with the image of his body, and it was the notion of the mirror stage that worked this encounter. Rivera reminds us that in the movement of identifying with his/her image, the child is not alone, because there is another there (who supports him/her), and the baby turns to this person to confirm that this image is him/her.

In addition to drawing attention to this structuring function of the other, Rivera shows that there is, in this game of recognition, an aspect little emphasized by psychoanalysts: 
by identifying with this image in the mirror, the baby begins to gesture, experiencing the space around him, and, with this, he confirms the recognition at the same time that he experiences the fact that this image is not him, because he realizes that those gestures are born from a place outside the mirror. That is, the mirror provides the anchor for identity while establishing a space outside the mirror, the space of the real body.

She points out that the image is always in this play between illusion, covering, and presenting something beyond itself. This bodily presence that is inside and outside the mirror is an important theme in psychoanalysis, at least since Freud (2010/1919) started talking about the strange. This is because the stranger indicates this passage between the appeasing narcissistic recognition of our identity and the radical questioning of our position in the world, through a breaking of that identity. In this sense, Rivera agrees that, fulfilling the function of the mirror, we now have the photographs and - we can add - the selfies.

The literature review on the subject shows that the Brazilian studies that focus on the meanings of selfies have been conducted in the field of Communication and not Psychology. And, even though they perceive the expression of subjectivity in this photographic modality, they tend to relate selfies only to narcissism. Studies in Psychology investigate photography or social media as a whole, as can be seen in Khouri (2015), Lima, Moreira, Stengel and Maia (2016) and Souza (2015). In other countries, there is more scientific production on the subject, and the search for the descriptors "selfie" and "youth" brings relevant results from the last five years. However, it was found only one Canadian sociological study in which young people were asked to talk about their experiences with selfies, from which were extracted three types of relationships with the images: the relationship of control, the relationship of visibility and the relationship of fun (Cambre \& Lavrence, 2019).

No other psychoanalytic research was found that proposed to work with categories of meanings that young people attribute to their own selfies. Based on these questions and on our research conducted between 2017 and 2019, this study aimed to investigate the phenomenon of selfies on social networks, identifying the meanings produced by young people about their selfies and seeking to expand the understanding about this modality of photography.

\section{Method}

A qualitative research was carried out, an approach that understands that human action always has a meaning that cannot be understood only from an objective point of view. The data was collected through structured interviews, which sought to understand a particular phenomenon and, at the same time, to promote reflection and emancipatory action in the research participants themselves.

Applied psychoanalysis was used to guide the reflection about the meanings that selfies have for them. It is known that, besides being a theory and a form of treatment, psychoanalysis is a research method that extends to the analysis of culture, social and daily experiences (Rosa, 2004). By conceiving the fundamental rule of psychoanalysis, Freud established the form of access to the subject of the unconscious, which makes transference the unique path and structuring condition of the methodology of research in psychoanalysis, so that psychoanalytic research of social phenomena, besides being guided by transference, makes use of free association and floating attention as techniques.

\section{Participants}

The sample was composed of 15 college students between 18 and 28 years old, selected by convenience. The participants were recruited for being inserted, throughout their lives, in the context of proliferation of digital photography in Brazil, as well as for indicating constant contact with photography devices and social networks.

\section{Instruments}

Interview. During the interview and using his personal smartphone, each youth was asked to choose five personal selfies posted on some social network and to answer two questions about them: (1) Why was this photo taken?; (2) Why was it shared? No scales or psychometric instruments were used.

\section{Procedure}

Data collection. According to the data saturation criterion, 30-minute face-to-face interviews were conducted through the Snowball procedure, in which each of the participants indicated the next participant. The structured interview took place on university campuses and presented itself as a method of data production suited to the research objectives, coupled, however, with the incitement of a choice by the interviewees - the choice of selfies to talk about. It is worth clarifying that the number of five images was thought taking into account the possibility of analyzing the volume of material that would be produced and, in fact, all this material was analyzed.

Data analysis. This is a psychoanalytic research, in which the material collected was analyzed according to the interpretative method in its dimension of extension to cultural phenomena, the "applied psychoanalysis" (Freud, 1980/1917). From this, and so that categories could be created, the interviewees' narratives were put in dialogue with discussions on contemporaneity, with the desire and demand captured by listening to the authors and with the transfer aspects experienced in the interviews.

\section{Ethical Considerations}

The research was approved by the Ethics Committee for Human Research at Universidade de São Paulo (CAAE No. 4618317.1.0000.5561, Opinion No. 2.310.773). 


\section{Results}

What immediately drew attention in the interviews was the fact that "making the photo" and "publishing the photo" were treated undifferentiated by them. This element makes one think that, for these young people, the intention of making photographs is so conditioned to sharing them with others that it makes no sense to treat them as individual acts. It is almost as if they returned with another question: but it is not to share that we make photos?

The interviews were surprising, due to the fact that there were several senses produced by young people when narrating their selfies and publications. We created categories of narratives that reflected our analysis of the elements that appeared privileged in the interviewees' speech and fixed the meanings we captured during the interviews - meanings that are not mutually exclusive, but interact with each other. They are: the obligation to publish experiences and present oneself in a glamorous way, in the imperative selfie; the game of making manifest something that is known to be false or untrue, in the fake selfie; the recognition of something strange in the images, in the disturbing selfie; the constitution of a new way to compose and store memories or to pay homage, in the memory selfie; and the attempt to get around the feeling of anxiety and loneliness, in the selfie demand for love.

\section{Imperative Selfie}

The selfie as a social task appears recurrently in the interviewees' speeches, often as a background for another more specific justification. Several young people seemed to think of the production of selfies as a responsibility that should be explored, since it would constitute one of the rules that govern life and coexistence with others.

Some referred to the idea of accountability to society, as in these statements: "This one was because I went to the show and I had to take a picture there, right?"; and "This one I took to show my tattoo, because I hadn't shown it yet". Both tried to point out that they only did what was necessary, what was expected of them. It is worth reflecting who occupies the role of the one who makes such demands. Is it society? Or the social networks themselves? In this sense, it would be possible to see them as a technological entity that, by taking selfies of others, asks the person scrolling through the screen: "And you, how have you lived your life? What have been your latest achievements? Have you done everything that is best and most socially valued?". One should answer this question with a selfie, a representation of the experiences one has had.

The selfie also seems to serve the exercise of popularity and its consequent duty to guide others, as is evident in this narrative: "This one I took at Carnival. I like to show that we can make several different costumes with what we have at home". Even popularity, here, is seen as a task, a call to fulfill certain responsibilities towards other people. In this sense, the narrative of the young woman interviewed indicates that her sharing benefits those who receive the shared content, more than herself, and that therefore her selfies do a favor to those who look at them.
Other narratives that made us think of the selfie as a presentation of the self with glamour: "In this one I was at a party, and when you go to a party, you have to show that you went there"; and "I thought I was handsome in this one, I had a nice face, with a neat beard. It's one of the things that makes us post, right?". When talking about the beard, the young man explains that his identification with a socially valued ideal of beauty is a recurring motivation for sharing photos on the web, being a way to say: "I'm not exactly like this, but in this moment I was corresponding to what is valued".

A strategy also indicated by the young people is to present themselves with differentials that would put them in the spotlight, as is indicated in these two statements: "In this one I had been to the speech therapist and then I took a picture outside, because we singers have to go. There are people who don't care about that, so I wanted to pass on this message that I take care of myself, that I am responsible"; and "This one was at Carnaval. Each one received a costume, and mine was a Captain America costume, and I thought it was great. So I posted it because everybody likes superheroes".

In the narrative about consulting the speech therapist, it has been characterized as an indirect way of placing himself in a prominent position over others, presenting himself as a singer who respects professional guidelines. In the second narrative, the line of reasoning that motivated the young man to make the publication is outlined: "If everyone likes superheroes, everyone will like me".

What becomes evident in the following narratives is that the reference for this place considered of prominence is the one presented by famous people or highly publicized in the media: "We kind of tried to imitate the famous people, you know? The famous people who have big mouths in the picture"; and "This one here because I was in this bar with my friend, and she took it. I wanted to take one from this day; to show this beautiful and fashionable dress". The goal is to generate publishable photos, which, in the young people's conception, by matching those of prestigious people, can only bring them prestige as well. In this sense, it is emphasized by them that they need the selfies to prove that they have had experiences that are socially valued, at the exact moment when the culture advocates that they should happen.

It was also possible to conjecture that photos on social networks should be spectacular. This is demonstrated by a young woman who presents the reasoning used around the posted selfie: "It seems that I take pictures, and then they are outdated, understand? But I posted it anyway, I was afraid not to use this photo on social networks. It would be a waste". The idea of "waste" makes one understand the contemporary imperative that if something is interesting (in any sense), it should be used to benefit from it on social networks.

\section{False selfie}

Frequently, young people admitted that they use selfies to share lies, something that would express a certain freedom for this in the universe of social networks. This could be observed in statements such as: "This is when my sister 
came four days before my birthday. I said: 'Let's take some pictures for my 20th birthday. This picture was good, and then I posted it to mark the date"; "This was the day I took my godson on the Ferris wheel. He was excited, he thought it was very exciting. Then he did the first lap, and he was disappointed, asking if nothing else would happen. Then I posted a picture of the time of the line, when he was still excited, you know?"; and "This was when the bus ran aground on the hillside, and everyone had to get off. I said: 'Let's get together and take a picture of this funny moment. Wow, the people were really desperate. I also said: 'People, hold on to your ID, because if the bus crashes, it will be easier to identify everyone".

The three narratives show that the feeling they tried to convey when they published the selfie was different from the feeling they experienced at the moment they took it. However, it is possible to perceive the belief of young people that this is exactly how social networks work - they expose the beautiful and the interesting, but always implying that this is a snapshot of a reality that was, in many ways, different from this.

It is clear that the time it takes to make selfies does not have to be the same as the time it takes to share them on the web. About this, a young man also reveals that: "To be able to select I take many. I took several that day, to choose only one. And maybe I don't like the picture today to post it, but in a few days I will like it and then I will post it". But one line in particular draws attention for trying to differentiate between a real selfie and a fake selfie: "It was Mother's Day. Everyone was posting pictures with their mothers, so I went to try to take a picture with her, but I thought it was so artificial, so unrelated. Then I looked through my photos, and I saw that this one had been taken on a random day and I thought it was a much truer and meaningful selfie, so I decided to post it. Even though it was a selfie, it was not an obligation like 'Oh, I have to post it on the social network'. It was a more relaxed selfie”.

One young man's narrative reveals that: "In this one I was going to start a show, so I got a glass of juice, pretended it was a glass of wine, and took it making a toast. Actually, that day I had had an argument, I was about to end my relationship, I was very sad, but I took this picture and wanted to publish it". This narrative carries the weight of a confession about the real phenomenon that the selfie tried to cover up, which was the fact that the young man was living a moment of intense suffering, and also demonstrates one of the characteristic facets of the society of the spectacle: the notion that if in the image you are toasting, it's okay.

In the same direction, a term that appeared in some moments, playing with the notion of true and false, was "spontaneous", which is used in a caricatured way in these narratives: "In this one I said: 'I'm going to make some poses and you keep taking them, because I want spontaneous'. But it wasn't really spontaneous. They are the best, these false spontaneous ones"; and "This one is at a graduation. When I ask someone to take a picture, they usually take several, and since it was one of the spontaneous shots, I liked it".
These narratives make one think about the relationship between the handling of selfies and Winnicott's notion of true and false self (1975/1971). In the Winnicottian sense, would selfies be taken by young people as a form of imitation or as creation? Do they represent a spontaneous gesture or the submission to fads?

The narrative about Mother's Day, calls into question the difference between making a photo for its own sake (which is not made with the intention of being posted) and making a photo for the fact that everyone is making and posting it, which means that everyone is "expected" to do it. Putting this differentiation in dialogue with the idea of Winnicott's spontaneous gesture, it is possible to delineate that the value of each selfie can vary for each individual, and this will depend on the quality of the lived experience: if the selfie has a sense of creation and is a means of spontaneity for the individual, it could contribute to the exercise of the true self, while if it has the sense of imitation, what could be glimpsed is an expression of the false self. That is, the selfie can be configured as an expression of the true self as well as a false self, and this bifurcation is a problem that will also appear in the next topic, when the issue of the stranger will be discussed.

First, however, it is worth pointing out that in some moments the interviewees show explicit awareness of the element of "social task" and the clash "creation versus imitation" present in the experience with selfies. This is what the young man demonstrates when he says: "I took this one because of the light and the colors. It's a media culture thing. I'm very concerned about this business of combining feed colors. So it was because of the chromatic palette. I looked for a bright place, a way to combine green, yellow and beige".

\section{Unsettling Selfie}

Speaking of lighting, it is striking how often young people mention the sun or the light they used to make the photo. Some explained: "This one I posted because of the sun. I love the sun, it's a nice effect"; "I took this one because I thought it was a nice effect. It gave a reflection of the sun. Then I loved it. So I took it". Young people seem to indicate that the presence of sunlight is a complete justification, which is enough by itself as the ultimate reason for the selfie.

However, if light has such a valuable meaning, what is this meaning? To help the reflection, some more narratives are recalled: "I like it when the sun shines, because it kind of hides the defects on my face, you know? And the light was very good!"; "The sun was beautiful this day! When we watch these series, like American's Next Top Model, we always see the tips: 'Look for the best light, the best angle'. And that day, I said: 'Since the sun is beautiful, let me take a picture here".

The young man's line that says "look for the best light, the best angle" represents well what has been observed in the universe of digital glamour: to make a successful selfie, it is necessary to use natural light at the right time, in the right way, in the right place. Interesting to note that in some moments the light is indicated as that which fortunately reveals, but also fortunately hides something in the subject, 
which refers to Freud's stranger (2010/1919). Light seems to be advantageous for young people when it is a way to hide defects, but it is also advantageous when it shows off qualities - both aspects that make the selfie more attractive.

And, in the same direction, we could notice other narratives that do not mention the light itself, but that also bring the aspect of revelation and concealment, as in: "I think it was because I liked my eyeliner, it was right. In fact, it didn't even show in the picture, but I liked it"; or in: "It was the first picture of the party, and I liked it a lot. It was a picture I took as a joke, just to save the makeup".

In both accounts, the makeup appears as something that gives a new meaning to the corporal experience of the interviewee, and there is also a certain surprise in the interviewee's encounter with the registered image. We must remember that Freudian strangeness is not linked to any surprise, but to what, besides being already known (unconsciously), is disconcerting for the subject, uncomfortable, disturbing. Freud (2010/1919) makes it clear that the study of strangeness is a study of aesthetics, not in the sense of the theory of beauty, but of the qualities of feeling. Thus, it is an affection, which, at the same time that it deals with the subject's contact with something that arouses horror, reveals his desire. The desire in question represents a narcissistic hole, a shattering of narcissism that would demonstrate that the subject is not the master of his or her own dwelling (Freud, 1980/1917).

Here it is also difficult to state that young people publish the selfies in an attempt not to get in touch with the stranger of the self or that the publication is done to nurture a certain enamoring with it. In the direction of what Butler (2015, p. 105) states, the question proposed by contact with the stranger would be, "Who is this you that resides in me, from which I cannot separate myself?". And the selfies seem to give place precisely to the ambiguity present here, showing themselves as a form of identification of the subject with himself as well as recognition of his own change. We should reflect about what can be considered "the strange" for the young people interviewed (would it be the non-correspondence with what is socially valued?), and even if it would be possible to gather these young people around a single answer.

\section{Memory selfie}

The memory of moments lived is also an element that emerged. Sometimes, the social network is seen as an ideal repository of memories: "This one I took with relatives. I liked it because it would be a souvenir photo, so I'll save it on Facebook".

In this sense, there are also examples that cite trips and places visited that one wants to remember with a clarity that memory would not allow, such as: "This one because I was traveling and I was feeling very happy, very full, and I wanted to remember that"; "This one because it was the last holiday, and I wanted to post it before I left to remember how I was feeling"; and "This one was on a trip. When I travel, I always take a picture like this".
There are also references to collective experiences that need to be stored: "This one I was in a nice moment with all my friends, you know? I think it was a good photo, that transmitted this moment to me". The young man's formulation that the photo "transmitted this moment" to him draws attention. One can think that if the selfie had not been taken, the moment would not have been observed or validated in a complete way.

There are even mentions of moments of great intimacy and sentimental value that could be stored with the touch of preciousness, as can be seen in: "It was when I met my halfsister. I was getting to know her and it was really good"; or in: "My cousins had just moved into the apartment. So we went to the inauguration and took this family selfie. I said: 'Guys, let's register this moment! They are starting a new life!" This last narrative and the invitation it imposes evoked the idea of toast, so common in celebration rituals and today treated as a symbol of friendship and jubilation. Wouldn't selfies, then, also be symbols of celebrations and ceremonial milestones? A new form of toast, perhaps.

The presentation of this "family selfie" even refers to the proposal that the selfie is not limited to a photograph of a subject's face. The same appears when the intention is to pay homage, as is indicated in these excerpts: "The restaurant was named after our friend. We took a picture to send it and show that we remembered him"; "This one is with my cousins. We post a picture when we really like that, that moment or that person"; "This was on my father's birthday. We went out to celebrate, and then I wanted to take a picture because of the birthday. I posted it to pay homage to him". As a gift or a present, selfies seem to represent a form of accepted tribute, an instrument that mediates the expression of different situations of gratitude.

\section{Love demand selfie}

Some young people were anxious about the phenomenon of selfies and social networks, so that both participating and not participating in the current sharing movement seems to be likely to be lived as an anxiogenic experience. One of the young women brought an important revelation about the relationship she established with the network, which seems to be configured as an attempt to spare her from the experience of loneliness: "Sometimes you are alone and there is no one to tell what is going on, and you get desperate thinking: 'Oh my God, this is happening! There's nobody here to see it, so I'll tell them".

The young woman shows that her posts do justice to the social network idea of sharing, if we think of this term as referring to sharing. It is not possible to risk the conclusion that this sharing fulfills its function and that the young woman's demand is met. For this, it would be necessary to investigate in depth if a relationship with the other becomes possible and what is the quality of this encounter that the young woman proposes. However, it is possible to perceive her desire and attempt to establish a relationship.

Another interviewee even revealed that one of the ways to use the web and relate to it is precisely the possibility of 
calling it into question: "I was having an existential crisis and made this montage. Because of the sentence that I put together, I think I was feeling bad, because directly I feel that I don't fit in, you know? So sometimes taking a picture like this helps me to express myself, to tell the world that I am not feeling well".

Many young people give indications that they use selfies as a strategic tool to survive this condition of pain, of otherness absence, as when the young woman says: "there is no one to tell what is happening, and you get desperate". But there is still another example of this element, which reveals a little more of the artifices that are used to help them feel part of the network: "I've taken a lot of selfies of animals... Very famous ones, right? I wanted to post this one because I always think I look good, much more beautiful than I am".

It is clear that filters walk in line with contemporary imperatives on the body and on experiences, offering a true "makeup" for what will be shared with others, always with the aim of beautifying or spectacularizing. The young woman talks about the distortion promoted by these tools and about the false presentation of the self on social networks, which seems to be increasingly stimulated by the growing invention of new filters and the ease of their use. The idea that circulates seems to be that if improved, the subject matches what is expected, and thus can be part of the social bond, which frees him (quite precariously) from the feeling of loneliness and abandonment.

\section{Discussion}

Between 2012 and 2014, Trivundža (2015) analyzed 255 articles from UK media and noticed that the psychopathologization of selfies prevails in the analyzed articles, while the phenomenon should be understood, in the author's opinion, as communicational sociological. But despite the tendency of national and international studies to relate selfies only to narcissism and emphasize the harmful potential of social media (Srivastava, Chaudhury, Prakash, \& Dhamija, 2020; Stuart \& Kurek, 2019), this research brought new possibilities to look at the phenomenon.

The interviews brought out an ambiguous way of showing oneself to the youngsters, and the selection of images constituted a game of projections. The selfies could be understood as a metaphorical object, and that, therefore, are endowed with multiple meanings. The formulations of Sibilia (2016), even help to mark what then emerged in the interviews: the selfies not only testify, but also organize and give reality to the lived experience.

Butler (2015) draws attention to our fundamental dependence on the other, due to which we cannot exist without questioning him or her and without being questioned by him or her. The author recognizes that this questioning takes place in the molds of the discursive regime and the socio-historical horizon in which one lives. Thus, the molds of contemporaneity could not fail to suggest photographs and social networks as a tool for such interpellation, and the suggestion to adopt this tool with the goal of questioning the other has important impacts on contemporary subjectivities. Burns (2015) also indicates that not only selfies, but also the discussion about this practice, reflect contemporary social norms and anxieties, in order to fulfill a regulatory social function. However, an important aspect observed is that addressing the other through selfies conveys diverse and very unique narratives, which differ from person to person and from selfie to selfie.

Another 2017 study set out to assess whether young people who take selfies have low self-esteem, but concluded that statistical analysis could not confirm this correlation (Fejes-Vékássy, 2017). For Sontag (2004/1977), the real reason for this need to photograph everything lies in the very logic of consumption itself. She reminds us that "to consume" means to burn out, to exhaust and, therefore, to have to replenish. In this respect, we can perceive a kind of compulsion nowadays, which seeks, through consumption, to obtain full enjoyment and satisfy the subject. But here the question arises: has the object of desire ever satisfied?

In the sense of this reflection, the contribution of B.P.M. Rocha, Rosa and Degani (2014) is to suggest that it would not have been the social networks that made the world problematic, relationships insecure and men individualistic. The time before current technologies may often seem more reliable and stable, but this way of looking at the past disregards the problems that were experienced at the time and that had to be faced with the use of other tools. The perspective is that this uncritical view of history is produced by the effect of the recalcitrant and proposes an unfair comparison between complex times that have particularities. According to their proposition, then, the unbridled search for recognition and likes should not be seen as a novelty detached from other times.

Thus, we can understand that begging for likes, sharing selfies, and making life photographable is an attempt at subjectivation, a way of dealing with emptiness and the anguish of being a subject. But this does not mean that they are worse or regressed strategies and tools. Selfies, in this sense, are attempts not only to sustain the subject's narcissism, but also to capture the other from whom he seeks recognition.

Still on the demand for love, it is necessary to consider that desire is conceived as a hallucinatory search for a first object of satisfaction, which is given as lost forever. Thus, the desire can be realized, but never satisfied. When an object is finally found, the subject is returned to the first object and thus begins a new search. What remains in desire is always lack, conferring desire to the regime of the unconscious, the stranger of the self. Lacan (2008/1969) adds further that the imaginary dimension of the desire of being is to fulfill the other's desire, that is, to correspond to the other's supposed expectations, to be recognized and loved by him, and this throws the notion of desire into an endless void, in which there is no object that can one day fill it (Torezan \& Aguiar, 2011).

This goes along with the idea that, despite being a possible tool today, the selfie needs to be repeated when it is missed. It fulfills, for the subject, the same function as 
other artifices from this and other times, which is to allow him to be in the culture. Some narratives pointed out that it is precisely the feeling of strangeness that moves young people to publish on the social network. But what would this estrangement be? It is worth wondering if it would not be the discovery of the condition of helplessness and the search for belonging. Studying the behavior of young people who take selfies in memorable places, Douglas (2020) proposes that, although common sense sees the selfie as a self-centered response, this form of photography even represents a form of testimony about community events.

It is necessary to remember, also, the speech of an interviewee who intended a possible differentiation between true and false selfie. It seems to exist, both in this statement and in recurrent reflections about the phenomenon, the idea that we lie to others in selfies. What effects would these lies have, then, especially given the expectation that the publications are really fabricated lies or edited realities? It is worth remembering the understanding indicated by Freudian propositions that the human being is not even transparent to himself, since the self denies precisely what the unconscious affirms and desires (Han, 2017), what makes one think that the inventions in the selfies are close to the inventions that are proper of the subject's dealings with him or herself - his or her subconscious - and with the world.

This reflection also brings to bay the Winiccottian notion of true and false self, according to whom the false self seeks to circumvent environmental flaws that hinder the expression of spontaneity, making the subject submit to certain socially instituted conditions in order to survive and protect the true self. In this sense, we reflect that, depending on how young people experience and relate to the selfie, it provides them with different types of subjective effects, more or less in line with the social dictates. Selfies would serve the subject as this narrative metaphor that works as a strategy in the constitution of subjectivity. This strategy is supported by the look that awakens the other, so that, although the contemporary subject is increasingly considered as selfreferred, it relies on the feedback it receives to put itself in the process of reviewing and redefining itself.

The idea of the narrative metaphor makes one think of Freud's "Covering Memories" text (1976/1899). It is possible to understand that covert memories are constructed unconsciously, almost like works of fiction, usually in the form of childhood scenes. The key point of the text is the notion that it is necessary to analyze the memories in order to understand their meaning, since at first sight they may seem insignificant. And this question makes one think that the same movement was propitiated by the interviews, which, by asking the youths about the motivations behind the photographic record and its sharing on the Internet, opened the possibility of analyzing "covering memories" and reconstructing symbolic links between the photographic records and the lived experience - be it real or fantasy.

It is possible to consider, then, that selfies can sometimes be cloaked in covert memories for their authors, but maintaining symbolic relationships with the experiences concretely lived. In this sense, our research has shown that we are in a time when the selfie and its sharing with others enable the construction of a narrative of the self that gives new meaning to the experience lived and enables developments to it. These results revealed relevant points that are little or not discussed in the literature on the subject. We can only insist, then, on the plurality of meanings and the complexity of the selfie phenomenon, emphasizing the contribution of this study in broadening the interpretation of the use that young people make of social networks and in opening new perspectives for the work on this theme in contemporary psychological practice.

It is known the sociocultural limitations of the categories of narratives created, because only Brazilian college students were interviewed. For an even greater scope of understanding about the meanings that selfies have on youth, it is suggested that further research could also focus on the narratives of young people who do not belong to the Brazilian university class.

\section{Referências}

Almeida, F. C., \& Severiano, M. F. A. (2017). Selfie e teoria crítica: Considerações acerca do trabalho com imagens em psicologia [Selfie and critical theory: Considerations on the work with images in psychology]. Revista de Psicologia, 8(1), 121-128.

Birman, J. (2016). Sexualidade e narcisismo nos arquivos da psicanálise [Sexuality and narcissism in the archives of psychoanalysis]. In J. Birman, L. Fulgencio, D. Kupermann, \& E. L. Cunha (Orgs.), Amar a si mesmo $e$ amar o outro [Loving yourself and loving the other] (pp. 23-41). São Paulo, SP: Zagodoni.

Burns, A. (2015). Self(ie)-discipline: Social regulation as enacted through the discussion of photographic practice. International Journal of Communication, 9, 1716-1733. Retrieved from https://ijoc.org/index.php/ijoc/article/ view/3138/1395

Butler, J. (2015). Relatar a si mesmo: Crítica da violência ética [Giving an account of oneself] (R. Bettoni, Trans.). Belo Horizonte, MG: Autêntica.

Cambre, M.-C., \& Lavrence, C. (2019). How else would you take a photo? \#Selfieambivalence. Cultural Sociology, 13(4), 503-524. doi:10.1177/1749975519855502

Douglas, K. (2020). Youth, trauma and memorialisation: The selfie as witnessing. Memory Studies, 13(4), 384-399. doi: $10.1177 / 1750698017714838$

Estevão, I. R. (2016). Narcisismo histórico ou constitutivo: Entre a sociedade narcísica e o exercício da singularidade [Historical or constitutive narcissism: Between narcissistic society and the exercise of singularity]. In J. Birman, L. Fulgencio, D. Kupermann, \& E. L. Cunha (Orgs.), Amar a si mesmo e amar o outro [Loving yourself and loving the other] (pp. 128-138). São Paulo, SP: Zagodoni. 
Fejes-Vékássy, L. (2017). Self(ie)-esteem? A manifestation of adolescent self-creating endeavours in the virtual space of Facebook. Journal of Education Culture and Society, 8(2), 221-227. doi:10.15503/jecs20172.221.227

Freud, S. (1976). Lembranças encobridoras [Covering memories]. In J. Salomão (Ed.), Obras completas de Sigmund Freud [Complete works by Sigmund Freud] (J. O. A. Abreu \& C. M. Oiticica, Trans., Vol. 3, pp. 285-306). Rio de Janeiro, RJ: Imago. (Original work published 1899)

Freud, S. (1980). Conferências introdutórias sobre psicanálise: Conferência X - Simbolismo nos sonhos [Introductory lectures on psychoanalysis: Conference X - Symbolism in dreams]. In J. Salomão (Ed.), Obras completas de Sigmund Freud [Complete works by Sigmund Freud] (C. M. Oiticica \& V. Ribeiro, Trans., Vol. 15, pp. 287-539). Rio de Janeiro, RJ: Imago. (Original work published 1917)

Freud, S. (2010). Introdução ao narcisismo [Introduction to narcissism]. In Obras completas [Complete works] (P. C. Souza, Trans., Vol. 12, pp. 13-50). São Paulo, SP: Companhia das Letras. (Original work published 1914)

Freud, S. (2010). O inquietante [The unsettling]. In Obras completas [Complete works] (P. C. Souza, Trans., Vol. 14, pp. 328-376). São Paulo, SP: Companhia das Letras. (Original work published 1919)

Freud, S. (2014). Inibição, sintoma e angústia [Inhibition, symptom and anguish]. In Obras completas [Complete works] (P. C. Souza, Trans., Vol. 17, pp. 13-123). São Paulo, SP: Companhia das Letras. (Original work published 1926)

Green, A. (1988). Le travail du négatif [The work of the negative]. Paris, France: Minuit.

Grigoletto, E., \& Wanderley, R. K. K. (2016). A narrativa de si em blogs de moda feminina: Entre a subjetividade $e$ a alteridade [The self-narrative in women's fashion blogs: Between subjectivity and otherness]. Revista Desenredo, 12(1), 64-81. doi:10.5335/rdes.v12i1.5955

Han, B.-C. (2017). Sociedade da transparência [Society of transparency]. Petrópolis, RJ: Vozes.

Khouri, M. G. (2015). Fotografia: Realidades e ficções [Photography: Realities and fictions]. Ide (São Paulo), 37(59), 97-98.

Lacan, J. (2008). O seminário, livro 16: De um outro ao outro [The seminar, book 16: From one another to the other]. Rio de Janeiro, RJ: Jorge Zahar. (Original work published 1969)

Lima, N. L., Moreira, J. O., Stengel, M., \& Maia, L. M. (2016). As redes sociais virtuais e a dinâmica da internet [Virtual social networks and the dynamics of the internet]. Gerais: Revista Interinstitucional de Psicologia, 9(1), 90-109.
Razé, A., \& Sibilia, P. (2015). Narciso no espelho do século XXI [Narcissus in the mirror of the 21st century]. Retrieved from https://www.narciso21.com/

Rocha, B. P. M., Rosa, C. T., \& Degani, R. (2014). No meu tempo não era assim ou o que dezemos quando dizemos sociedade do narcicismo? [Wasn't it in my day or what we say when we say narcissism society?]. In Centro de Estudos Psicanalíticos de Porto Alegre, Para uma introdução do narcisismo [For an introduction to narcissism] (pp. 206-219). Porto Alegre, RS: IPSDP.

Rocha, Z. (1999). Desamparo e metapsicologia: Para situar o conceito de desamparo no contexto da metapsicologia freudiana [Helplessness and metapsychology: To situate the concept of helplessness in the context of Freudian metapsychology]. Sintese - Revista de Filosofia, 26(86), 331-346.

Rosa, M. D. (2004). A pesquisa psicanalítica dos fenômenos sociais e políticos: Metodologia e fundamentação teórica [Psychoanalytic research of social and political phenomena: Methodology and theoretical foundation]. Revista Mal-Estar e Subjetividade, 4(2), 329-348.

Sibilia, P. (2016). O show do eu [The show of self]. Rio de Janeiro, RJ: Contraponto.

Sontag, S. (2004). Sobre fotografia [About photography]. São Paulo, SP: Companhia das Letras. (Original work published 1977)

Souza, R. N. C. (2015). Fotografia: O instante e o permanente [Photography: The instant and the permanent]. Ide (São Paulo), 37(59), 111-114.

Srivastava, K., Chaudhury, S., Prakash, J., \& Dhamija, S. (2019). Social media and mental health challenges. Industrial Psychiatry Journal, 28(2), 155-159.

Stuart, J., \& Kurek, A. (2019). Looking hot in selfies: Narcissistic beginnings, aggressive outcomes? International Journal of Behavioral Development, 43(6), 500-506. doi:10.1177/0165025419865621

Torezan, Z. C. F., \& Aguiar, F. (2011). O sujeito da psicanálise: Particularidades na contemporaneidade [The subject of psychoanalysis: Particularities in contemporary times]. Revista Mal-Estar e Subjetividade, 11(2), 525-554.

Trivundža, I. T. (2015). Are a thousand pictures worth a single word? The struggle between condemnatory and affirmative discourses on photographic change in Slovene and UK mainstream media news reports on selfies. Journal of the European Institute for Communication and Culture, 22(1), 93-109. doi:10.1080/13183222.2015.1017296

Winnicott, D. W. (1975). O brincar e a realidade [Playing and reality] (J. O. A. Aguiar \& V. Nobre, Trans.). Rio de Janeiro, RJ: Imago. (Original work published 1971) 
Isis Graziele da Silva is a Doctorate's candidate of the Postgraduate Program in Psychology at Universidade de São Paulo, São Paulo-SP, Brazil.

Daniel Kupermann is a Professor of the Universidade de São Paulo and a CNPq Scholarship Holder, São Paulo-SP, Brazil.

\section{Authors' Contribution:}

The author Isis Graziele da Silva made substantial contributions to the conception and design of this study, to data analysis and interpretation, and to the manuscript revision and approval of the final version. The author Daniel Kupermann made substantial contributions to the manuscript revision and approval of the final version. All the authors assume public responsability for content of the manuscript.

Associate editor:

Vanessa Barbosa Romera Leme

Received: Apr. 13, 2020

1st Revision: Jul. 09, 2020

2nd Revision: Sep. 03, 2020

3rd Revision: Oct. 29, 2020

Approved: Nov. 04, 2020

How to cite this article:

Silva, I. G., \& Kupermann, D. (2021). Selfie narratives made by young people. Paidéia (Ribeirão Preto), 31, e3111. doi:https://doi.org/10.1590/1982-4327e3111 